\title{
KUALITAS TIDUR ANAK USIA SEKOLAH YANG MENJALANI KEMOTERAPI DI RUMAH SAKIT KANKER
}

\author{
Novita Dewi Rahmayanti*1, Nur Agustini ${ }^{2}$ \\ 1. Program Studi Magister, Fakultas Ilmu Keperawatan, Universitas Indonesia, Depok 16424, Indonesia \\ 2. Fakultas Ilmu Keperawatan, Universitas Indonesia, Depok 16424, Indonesia
}

*E-mail: novitadewirahmayanti@hotmail.com

\begin{abstract}
Abstrak
Kemoterapi diyakini efektif dalam menghambat pertumbuhan sel kanker. Namun demikian kemoterapi juga menimbulkan efek samping bagi penderita kanker, salah satunya yaitu gangguan pemenuhan kebutuhan tidur. Penelitian ini bertujuan untuk mendapatkan informasi tentang gambaran kualitas tidur anak usia sekolah yang sedang menjalani kemoterapi di rumah sakit kanker. Penelitian menggunakan metode potong-lintang dengan melibatkan 40 responden yang diambil dengan teknik total sampling. Responden mengisi kuesioner berupa data demografi dan kuesioner Pittsburgh Sleep Quality Index (PSQI). Analisa data menggunakan uji univariat. Hasil penelitian menunjukkan rerata skor PSQI adalah 7 dari maksimal 21 (95\% CI, 6,24-7,76) yang berarti responden memiliki kualitas tidur buruk. Tenaga kesehatan (khususnya perawat) diharapkan dapat melakukan monitoring untuk evaluasi pemenuhan kebutuhan tidur anak kanker.
\end{abstract}

Kata kunci: anak usia sekolah, kanker, kemoterapi, kualitas tidur

\begin{abstract}
Quality of Sleep of School Age Children are Undergoing Chemotheraphy in Cancer Hospital Chemotherapy is believed to be effective in inhibiting cancer cell's growth. However, this therapy has side effects for cancer patients, one of them is sleeping needs disturbance. This study aims to get information about the status of sleep quality in school-age children whom are undergoing chemotherapy at cancer hospital, Jakarta. This study used cross sectional design with 40 participants using total sampling technique. Participants filled the questionnaire consisting of demographic data and the Pittsburgh Sleep Quality Index (PSQI). This study was analyzed using univariate test. The result showed that participants have quality sleep index with average score 7 from total 21 (95\% CI, 6,24-7,76). It's indicated that participants have poor sleep quality. Health providers (especially nurses) are expected to conduct monitoring to evaluate sleep quality in children with cancer.
\end{abstract}

Keywords: cancer, chemotherapy, school-age children, sleep quality

\section{Pendahuluan}

Angka kejadian kanker pada anak semakin meningkat. Tahun 2004 dilaporkan terdapat 160.000 kasus baru kanker pada anak usia 0-15 tahun di dunia. WHO juga mencatat 90.000 anak meninggal dunia setiap tahunnya karena sakit kanker. Beberapa faktor yang dapat memengaruhi diantaranya adalah kurangnya tingkat pengetahuan dan kesadaran masyarakat tentang kanker, tingkat ekonomi yang rendah, dan budaya masyarakat (WHO, 2010). Kanker pada anak tidak menunjukkan prevalensi tinggi seperti penyakit infeksius, namun kanker menempati sepuluh besar penyebab mortalitas pada anak di beberapa negara di dunia. Di Amerika Serikat dan Kanada pada tahun 2006, kanker menjadi penyebab kematian nomor dua pada anak setelah kecelakaan (unintentional injury) (Center for Disease Control/ CDC, 2007). Tahun 2005 di India kanker menduduki peringkat ke delapan sebagai penyebab kematian anak usia 5 sampai 14 tahun.

Prevalensi kanker di Indonesia menurut Yayasan Kanker Indonesia (YKI) diperkirakan 100 penderita kanker baru dari setiap 100.000 penduduk 
(Depkes, 2008). Pada prevalensi kanker pada anak 4,9\% dengan kasus terbanyak leukemia, sehingga paling tidak terdapat 4100 kasus kanker baru pada anak di Indonesia di tahun tersebut.

Data Rumah Sakit Kanker Dharmais (RSKD) (2013) menunjukkan telah terjadi peningkatan jumlah prevalensi penderita kanker pada anak. Pada tahun 2013 prevalensi kanker pada anak yang dirawat di RSKD leukemia 39\%, limfoma $10,63 \%$, osteosarkoma $6,38 \%$, rhabdomiosarkoma $6,38 \%$, neuroblastoma $5,67 \%$, retinoblastoma $4,25 \%$, tumor otak $3,54 \%$, karsinoma nasofaring $2,83 \%$, tumor germinal $2,12 \%$, kanker ovarium $2,12 \%$, tumor Willms $1,41 \%$, dan kanker/tumor lainnya $15,6 \%$. Dalam kurun waktu tiga tahun terakhir (2011-2013) urutan tiga besar kanker anak yang terbanyak di RSKD adalah leukemia, limfoma, dan osteosarkoma (RSKD, 2013).

Penanganan dan pengobatan kanker semakin maju dan berkembang. Hal ini membuat angka harapan hidup pada anak kanker semakin meningkat. Otto, Fulton, dan Langhorne (2007) menjelaskan bahwa harapan hidup pasien kanker selama lima tahun terakhir setelah pasien mendapatkan diagnosa pasti kanker meningkat dari 4\% di 1960-an menjadi $80 \%$ pada tahun 2000 .

Kemoterapi merupakan salah satu terapi pengobatan kanker yang dapat menghambat pertumbuhan dan membunuh sel kanker (DiSaia \& Creasman, 2007). Pilihan pengobatan melalui kemoterapi banyak menimbulkan efek samping seperti mual dan muntah, keletihan, ansietas, bahkan bisa mengalami gangguan tidur (Gedaly-Duff, et al., 2006).

Hasil penelitian American Society of Clinical Oncology menunjukkan bahwa sekitar 52\% pasien kanker melaporkan kesulitan untuk tidur karena insomnia. Sejumlah 58\% melaporkan bahwa penyakit kanker yang mereka alami menyebabkan perburukan pada kualitas tidur. Pasien kanker mengeluhkan bahwa mereka sulit untuk memulai tidur, memperoleh kepulasan tidur, dan merasa kelelahan di pagi hari.
Anak usia sekolah yang kanker juga diduga mengalami perubahan kualitas tidur. Pada tahap perkembangannya anak usia sekolah memerlukan istirahat dan tidur yang adekuat untuk mengakomodasi aktivitas keseharian anak yang tinggi. Tidur juga sangat penting dalam memelihara fungsi kognitif anak, seperti kemampuan berkonsentrasi, berpikir, belajar, dan menyelesaikan masalah pada tahap tumbuh kembangnya. Jumlah jam tidur normal untuk anak usia sekolah sekitar 10 jam per hari. Anak usia sekolah yang kanker perlu mendapat perhatian perawat dan orang tua agar anak mendapatkan jumlah tidur yang adekuat sesuai usianya.

Penelitian ini berfokus untuk mendapatkan informasi tentang gambaran kualitas tidur pada anak kanker usia sekolah yang menjalani kemoterapi. Hasil penelitian dapat mengevaluasi kecukupan tidur dan istirahat anak kanker. Selanjutnya, perawat dapat merencanakan terapi untuk meningkatkan kualitas tidur anak jika terdapat masalah pemenuhan kebutuhan tidur, baik melalui terapi mandiri maupun kolaborasi.

\section{Metode}

Desain penelitian menggunakan pendekatan kuantitatif potong lintang. Instrumen penelitian yang digunakan adalah kuesioner. Penilaian terhadap kualitas tidur anak kanker dilakukan dengan mengisi kuesioner karakteristik responden dan instrumen Pittsburgh Sleep Quality Index (PSQI). Data karakteristik responden terdiri dari jenis kelamin, umur, status pendidikan, tingkat pendidikan, kebiasaan sebelum tidur selama di rumah/rumah singgah, kebiasaan sebelum tidur di rumah sakit, kebiasaan yang mendukung tidur, jenis sakit kanker, lama periode kemoterapi, dan jenis obat kemoterapi yang diperoleh klien. Instrumen PSQI terdiri dari pengkajian terhadap kualitas tidur secara subjektif, waktu mulainya tidur, lamanya tidur, efisiensi tidur, gangguan tidur, kebiasaan penggunaan obat untuk membantu tidur, dan aktivitas sehari-hari yang terkait dengan tidur (Buysse, Reynolds, Monk, \& Berman, 1989). 
Instrumen yang digunakan dalam penelitian ini merupakan instrumen baku namun peneliti tetap melakukan uji validitas untuk menguji keterbacaan setelah dilakukan alih bahasa. Uji validitas dilakukan pada tiga anak kanker yang sedang menjalani kemoterapi di yayasan kanker di wilayah Jakarta. Hasil uji validitas didapatkan bahwa ketiga anak dapat memahami isi dan maksud pertanyaan dalam kuesioner, sehingga peneliti menyimpulkan instrumen dapat dipakai pada responden anak kanker usia sekolah di rumah sakit kanker.

Responden dalam penelitian ini sebanyak 40 anak yang dipilih dengan teknik total sampling. Analisis yang digunakan pada penelitian ini adalah analisis univariat yang dilakukan pada seluruh variabel penelitian. Untuk mengetahui status kualitas tidur responden, hasil penghitungan pada instrumen PSQI dikategorikan berdasarkan klasifikasi kualitas tidur, yaitu baik dan buruk. Instrumen PSQI memiliki rentang skor 0 sampai dengan 21. Skor total PSQI yang lebih dari 5 menunjukkan responden memiliki kualitas tidur yang buruk dan skor kurang dari atau sama dengan 5 menunjukkan kualitas tidur baik (Buysee, et al., 1989).

\section{Hasil}

Hasil penelitian diuraikan sebagai berikut: karakteristik responden (jenis kelamin, status pendidikan, tingkat pendidikan, jenis kanker); usia dan periode kemoterapi; penggunaan obat kemoterapi) dan kualitas tidur pasien kanker anak berdasarkan PSQI.

Tabel 1 menggambarkan responden perempuan lebih banyak dari pada laki-laki yaitu 21 (52,5\%) dengan status pendidikan responden mayoritas sekolah (70\%). Pada tingkat pendidikan didapatkan tiga urutan terbanyak responden yaitu kelas 1 SD (22,5\%), kelas 3 SD (17,5\%), dan TK dan SMP (15\%). Kebiasaan sebelum tidur di rumah, rumah singgah dan di rumah sakit yang paling banyak dilakukan yaitu menonton televisi sebesar $50 \%$ dan $37,5 \%$. Kebiasaan yang mendukung tidur responden adalah tidur bersama orang tua (30\%). Untuk jenis kanker diperoleh tiga besar kanker yang banyak diderita oleh responden yaitu leukemia (35\%), limfoma (25\%), dan osteosarkoma $(12,5 \%)$.

Pada Tabel 2 dapat dilihat bahwa rerata usia responden penelitian yaitu 8,7 tahun dengan interval kepercayaan 7,98-9,42. Sementara rerata periode kemoterapi yang telah dijalani responden yaitu 6,25 bulan dengan interval kepercayaan 4,31-6,25.

Tabel 3 menjelaskan bahwa obat kemoterapi dapat diberikan secara tunggal maupun kombinasi. Penggunaan kombinasi obat golongan antimetabolites dengan alkaloid tanaman dan kombinasi golongan alkylating agent dengan tanaman merupakan obat yang paling banyak digunakan yaitu masing- masing 15\%. Pada Tabel 4 menunjukkan bahwa rata rata skor PSQI anak usia sekolah yang men-jalani kemoterapi di rumah sakit kanker adalah $7(\mathrm{SD}=2,386)$ yang mengindikasikan kualitas tidur buruk.

\section{Pembahasan}

Anak usia sekolah berjenis kelamin perempuan yang dirawat lebih banyak. Hasil ini tidak sejalan dengan data dari Departemen Kesehatan RI (2005) yang memaparkan bahwa kanker pada anak laki-laki jumlahnya lebih banyak. Kualitas tidur paling baik dialami oleh anak perempuan $(23,81 \%)$. Hasil ini bertolak belakang dengan penelitian Burgard (2010) yang menyatakan bahwa perempuan memiliki kualitas tidur yang lebih buruk daripada laki-laki. Burgard menjelaskan $58 \%$ responden perempuan remaja dan dewasa awal memiliki kualitas tidur yang buruk disebabkan karena faktor stres, beban kerja, dan ketidakseimbangan hormon saat menstruasi dan kehamilan.

Status pendidikan responden yang bersekolah sebesar $70 \%$. Anak yang sekolah mayoritas memiliki kualitas tidur yang buruk $(67,85 \%)$. Anak yang tidak sekolah pun memiliki kualitas tidur yang lebih buruk daripada yang sekolah. Hal ini sejalan dengan penelitian Betz dan Sowden (2009) yang menyatakan bahwa anak biasanya merasa jenuh dengan proses pengobatan, hospitalisasi, 
dan keterbatasan aktivitas harian karena penyakit kanker. Responden penelitian paling banyak duduk di SD kelas 1 dengan jumlah 22,5 \% dari total responden. Distribusi tingkat pendidikan ini sejalan dengan penelitian Gurney (2005) yang menemukan data bahwa prevalensi anak kanker terbanyak pada usia sekolah.

Menonton televisi merupakan kebiasaan yang paling sering dilakukan anak sebelum tidur. Hal

Tabel 1. Karakteristik Responden Menurut Jenis Kelamin, Status Pendidikan, Tingkat Pendidikan, Kebiasaan Sebelum Tidur di Rumah dan Rumah Sakit, Kebiasaan yang Mendukung Tidur dan Jenis Sakit Kanker di RS Kanker

\begin{tabular}{|c|c|c|}
\hline Variabel & Jumlah (n) & Presentase (\%) \\
\hline Jenis kelamin & & \\
\hline a. Laki laki & 19 & 47,5 \\
\hline b. Perempuan & 21 & 52,5 \\
\hline
\end{tabular}

\section{Status Pendidikan}
a. Sekolah
b. Tidak sekolah

Tingkat Pendidikan
a. TK
b. SD kelas 1
c. SD kelas 2
d. SD kelas 3
e. SD kelas 4
f. SD kelas 5
g. SD kelas 6
h. SMP kelas 1

Kebiasaan sebelum tidur di rumah/rumah singgah
a. Menonton TV
b. Bermain game
c. Bermain internet
d. Membaca buku
e. Mengobrol
f. Lainnya

Kebiasaan sebelum tidur di rumah sakit
a. Menonton TV
b. Bermain game
c. Bermain internet
d. Membaca buku
e. Mengobrol
f. Lainnya

Kebiasaan yang mendukung tidur
a. Minum susu / empeng
b. Mematikan lampu kamar
c. Tidur bersama ibu/ ayah/ orang tua
d. Tidur ditemani mainan kesayangan
e. Lainnya
$6 \quad 15$
$12 \quad 30$

$\begin{array}{ll}8 & 20 \\ 6 & 15\end{array}$

Jenis sakit kanker

a. Leukemia

b. Retinoblastoma

c. Tumor otak

d. Neuroblastoma

e. Osteosarkoma

f. Limfoma

g. Lainnya

$\begin{array}{cc}14 & 35 \\ 1 & 2,5 \\ 0 & 0 \\ 2 & 5 \\ 5 & 12,5 \\ 10 & 25 \\ 8 & 20\end{array}$


Tabel 2. Karakteristik Responden Berdasarkan Usia dan Periode Kemoterapi Responden di RS Kanker

\begin{tabular}{lcccc}
\hline Variabel & Mean & Median & SD & 95\% CI \\
\hline Usia & 8,7 & 8 & 2,244 & $7,98-9,42$ \\
Periode kemoterapi & 6,25 & 4 & 6,071 & $4,31-6,25$ \\
\hline
\end{tabular}

Tabel 3. Karakteristik Penggunaan Obat Kemoterapi yang Diterima Responden di RS Kanker

\begin{tabular}{|c|c|c|}
\hline Kombinasi Obat & Jumlah (n) & Presentase $(\%)$ \\
\hline Alkylating agen & 5 & 12,5 \\
\hline Antimetabolites & 4 & 10 \\
\hline Antibiotik & 1 & 2,5 \\
\hline Alkaloid tanaman & 4 & 10 \\
\hline Alkylating agen, Antimetabolites & 1 & 2,5 \\
\hline Antimetabolites, Alkaloid tanaman & 6 & 15 \\
\hline Alkylating agen, Alkaloid tanaman & 6 & 15 \\
\hline Alkylating agen, Antimetabolites & 2 & 5 \\
\hline Alkylating agen, Anthracyclines & 5 & 12,5 \\
\hline Antimetabolites, Anthracyclines, Alkaloid tanaman & 3 & 7,5 \\
\hline Alkylating agen, Antimetabolites, Alkaloid tanaman & 2 & 5 \\
\hline Alkylating agen, Anthracyclines, Alkaloid & 1 & 2,5 \\
\hline Total & 40 & 100 \\
\hline
\end{tabular}

Tabel 4. Kualitas Tidur Responden Berdasarkan Skor PSQI di RS Kanker

\begin{tabular}{lcccc}
\hline \multicolumn{1}{c}{ Variabel } & Mean & Median & SD & 95\% CI \\
\hline Kualitas tidur subjektif $(0-3)^{*}$ & 1,1 & 1 & 0,632 & $0,9-1,3$ \\
Latensi tidur (0-3)* & 1,38 & 1 & 0,586 & $1,19-1,56$ \\
Durasi tidur (0-3) & 0,20 & 0 & 0,464 & $0,05-0,35$ \\
Efisiensi tidur (0-3) & 0,80 & 1 & 0,883 & $0,52-1,08$ \\
Gangguan tidur (0-3) & 1,9 & 2 & 0,545 & $1,73-2,07$ \\
Penggunaan obat tidur (0-3) & 0,15 & 0 & 0,362 & $0,03-0,27$ \\
Gangguan beraktifitas (0-3) & 1,48 & 1,5 & 0,640 & $1,27-1,68$ \\
PSQI $(0-21)^{*}$ & 7 & 7 & 2,386 & $6,24-7,76$ \\
\hline
\end{tabular}

ini dijelaskan oleh National Sleep Foundation (2013) bahwa tren kebiasaan yang paling banyak dilakukan oleh anak usia sekolah sebelum tidur adalah menonton televisi dan bermain games. Kebiasaan ini muncul sebagai akibat perkembangan teknologi dan kecanggihan peralatan yang memfasilitasi kebutuhan anak saat ini. Kebiasaan sebelum tidur yang paling banyak dilakukan oleh responden di rumah sakit juga menonton televisi.

Kebiasaan yang paling sering dilakukan anak untuk mendukung tidurnya adalah anak tidur bersama orang tua. Kebiasaan tidur bersama orang tua dilakukan oleh $30 \%$ responden penelitian. Anak-anak umumnya membutuhkan rasa aman dan nyaman sebelum tidur. Oleh karena itu anak biasanya memiliki kebiasaan-kebiasaan unik yang dilakukan sebelum tidur. Kebiasaan yang mendukung tidur seperti tidur bersama orang tua hendaknya mulai dikurangi secara perlahan pada anak usia sekolah (Klirgmen \& Arvin, 2009). Hal ini berkaitan dengan pembiasaan kemandirian anak untuk memenuhi kebutuhan tidur maupun yang lain. 
Jenis kanker yang dialami responden yaitu leukemia (35\%), limfoma (25\%), dan osteosarkoma (12,5\%). Menurut Departemen Kesehatan RI (2009) prevalensi leukemia merupakan kanker yang paling banyak diderita anak usia 0-17 tahun. Data Rumah Sakit Kanker Dharmais (2013) juga menyebutkan leukemia merupakan jenis kanker yang paling banyak ditemukan pada pasien anak tahun 2009-2013. WHO (2010) juga menyebutkan bahwa leukemia merupakan insiden kanker yang paling sering dialami anak di dunia. Mayoritas jenis kanker mengakibatkan kualitas tidur yang buruk bagi responden. American Cancer Society (2013) menjelaskan bahwa 85,3\% anak akan mengalami gangguan tidur pada awal diagnosis kanker jenis apapun dan saat menjalani pengobatan kemoterapi.

Golongan obat tunggal maupun kombinasi mengakibatkan kualitas tidur buruk pada responden. Penelitian Meckler (2009) menyebutkan bahwa $75,6 \%$ anak yang mendapatkan obat kemoterapi akan mengalami neutropenia, trombositopenia, dan anemia yang mengakibatkan reaksi radang (demam) yang mengakibatkan perburukan pemenuhan tidur anak.

Rerata periode kemoterapi yang sudah dijalani responden yaitu 6,25 bulan dari rentang 1-26 bulan. Variasi periode kemoterapi ini terjadi karena adanya perbedaan fase kemoterapi yang sedang dijalani responden. Responden ada yang masih dalam fase induksi, konsolidasi, maupun maintenance pada kemoterapi tumor padat dan fase induksi, konsolidasi, intensidikasi, dan maintenance pada tumor cair (RS Kanker Dharmais, 2013).

Kualitas tidur anak usia sekolah yang menjalani kemoterapi di rumah sakit kanker diukur dengan menggunakan instrumen PSQI yang memiliki rentang skor 0 sampai 21. Skor total PSQI yang lebih dari lima menunjukkan responden memiliki kualitas tidur buruk dan skor kurang dari atau sama dengan 5 menunjukkan kualitas tidur baik (Buysee, Reynolds, Monk, \& Berman, 1989). Kualitas tidur anak usia sekolah yang menjalani kemoterapi di rumah sakit kanker rerata nilai 7 dengan interpretasi kualitas tidur buruk. Hasil ini sejalan dengan penelitian Rosen dan Brand
(2011) yang dilakukan pada 70 anak kanker di Amerika, menyatakan bahwa adanya kualitas tidur yang buruk pada responden penelitian yang disebabkan kejadian insomnia, hipersomnia, dan gangguan bernafas.

Anak usia sekolah memiliki kerentanan untuk mengalami gangguan tidur yang berkaitan dengan peningkatan aktivitas anak seperti sekolah, ekstrakurikuler, bermain, dan kegiatan lain (Nutter, 2007). Pada penelitian ini selain anak berada pada masa usia sekolah, anak juga memiliki faktor predisposisi yang menyebabkan gangguan tidur yaitu sakit kanker dan menjalani kemoterapi.

\section{Kesimpulan}

Anak usia sekolah berjenis kelamin perempuan lebih banyak ditemukan pada penelitian ini dengan kualitas tidur yang lebih baik daripada laki laki. Responden memiliki rerata usia 8,7 tahun dari rentang anak usia sekolah yaitu 6-12 tahun Periode kemoterapi yang dijalani responden rata rata berlangsung selama 6,25 dari rentang waktu yaitu 1-26 bulan.

Responden yang menjalani kemoterapi di rumah sakit kanker memiliki skor kualitas tidur rerata yaitu 7 dari skor total 21 yang berarti kualitas tidur buruk. Jenis sakit kanker yang paling banyak diderita oleh responden anak usia sekolah yaitu leukemia, limfoma dan osteosarkoma.

Presentase masing-masing golongan obat kemoterapi yang diterima oleh responden yaitu alkylating agent, antimetabolites, antibiotik, anthracyclines, dan alkaloid tanaman. Penelitian ini menunjukkan bahwa obat golongan alkylating agent dan alkaloid tanaman merupakan obat yang paling banyak diberikan pada responden saat kemoterapi.

Hasil penelitian diharapkan dapat menjadi masukan bagi pelayanan keperawatan untuk membuat asuhan keperawatan yang lebih efektif pada pasien anak kanker yang memiliki gangguan pemenuhan kebutuhan tidur. Perawat dapat melakukan evaluasi kebutuhan tidur pasien dan kemudian dapat 
dijadikan dasar dalam memberikan terapi mandiri maupun kolaborasi (NN, INR).

\section{Referensi}

American Cancer Society. (2013). Cancer statistics in USA. Altanta: American Cancer Society.

American Cancer Society. (2011). Global cancer: Facts \& figures. United States: American Cancer Society.

Betz, C.L., \& Sowden, L.A. (2009). Buku saku keperawatan pediatri (Edisi ke 5). (Eny M., Penerj). Jakarta: EGC. Buku asli ditertibkan 2004)

Buysse, D.J., Reynold, C.F., Monk, T.H., Berman, S.R., \& Kupfer, D.J. (1989). ThePittsburg Sleep Quality Indeks (PSQI). Journal of Psychiatric Research, 28 (2), 193-213. Diperoleh dari http://findarticles.com/p/ articles/mi_mOFSS/is_4_12/ai_n 18616017.

CDC (Center for Disease Control and Prevention). (2007). Leading causes of death of children and youth. Diperoleh dari http://www.cdc. gov.

Departemen Kesehatan RI. (2009). Buku saku pencegahan kanker. Jakarta: Direktorat Pengendalian Penyakit Tidak Menular Departemen Kesehatan RI.

Departemen Kesehatan R.I. (2008). Profil Kesehatan Indonesia. Jakarta: Departemen Kesehatan RI.

DiSaia, P.J., \& Creasman, W.T. (2007). Clinical gynecologic oncology (7th Ed.). St. Louis: Mosby.

Gedaly-Duff, V., Lee, K., Nail, L.M., Nicholson, H.S., \& Johnson, K.P. (2006). Pain, sleep disturbance, and fatigue in children with cancer and their parents: A pilot study. Oncology Nursing Forum, 33, 641-646.

National Sleep Foundation. (2013). Annual sleep in America exploring connections with communications technology use and sleep. Diperoleh dari http://sleepfoundation.org/ media-center/press-release/annual-sleep-ame rica-poll-exploring-connections-communicat ions-technology-use-/page/0,1/.

National Sleep Foundation. (2013). Children and sleep. Diperoleh dari http://sleepfoundation. org/sleep-topics/children-and-sleep/page/0, 1/.

Nutter, D.A. (2007). Sleep disorder: problems associated with other disorders. Diperoleh dari http:// emedicine.medscape.com/article/ 916611-ov erview.

Otto, S.E., \& Fulton, J., \& Langhorne, M. (2007). Oncology nursing (5th Ed.) St. Louis: Mosby.

Rosen, S., \& Brand, S. (2011). Sleep in children with cancer: Case review of 70 children evaluated in a comprehensive pediatric sleep center. Supportive Care in Cancer, 19 (7), 985-994. doi: 10.1007/s00520-010-0921-y.

RS Kanker Dharmais. (2013). Registrasi Cancer. Diperoleh dari http://www.dharmais.co.id /index.php/registrasi-cancer.html.

WHO: Children's Health and The Environment. (2006). Cancer statistic in children. Diperoleh dari www.who.int/ceh.

WHO. (2010). Children's Health and the environment: Children and cancer. Diperoleh dari http://apps.who.int/iris/bitstream/10665/431 62/1/9241562927_eng.pdf

WHO: Children's Health and The Environment. (2010). Children and cancer. Diperoleh dari www.who.int/ceh. 